\title{
LIMA CARPON SUNDA UNTUK ALTERNATIF BAHAN PEMBELAJARAN MEMBACA CARPON DI SMA KELAS XI (Kajian Struktural dan Ekokritik)
}

\author{
Rahayu Nur Hikmah \\ MGMP Kabupaten Pangandaran \\ Pos-el: rahayunurhikmah@gamil.com
}

\begin{abstract}
Abstrak
Latar belakang dari penelitian ini adalah kurangnya kesadaran manusia dalam menjaga lingkungan. Tujuannya, menguak dan mendeskripsikan tentang struktur, ekokritik lima "Carpon" Sunda, serta bisa dijadikan sebagai alternatif bahan pelajaran membaca "Carita pondok" di SMA kelas XI sebagai hasil akhirnya. Metode yang digunakan adalah deskriptif-analitik. Hasilnya adalah 1)struktur dari lima cerpen, tema ("Pasir Kiara" tentang menjaga lingkungan, "Tanah Sakarung" tentang lingkungan politik dan religi, "Tempat Nyimpang Saheulaanan" tentang krisis ekonomi dan religi, "Katiga téh Teuing Ku Lila" tentang kerusakan lingkungan, dan "Séké Béntang" tentang menjaga lingkungan); alur maju ("Pasir Kiara," "Tempat Nyimpang Saheulaanan," "Katiga téh Teuing Ku Lila," dan "Séké Béntang") dan alur ganda ("Tanah Sakarung"); latar "Pasir Kiara" (21 tempat, 28 waktu, 22 suasana, 4 sosial), "Tanah Sakarung" (10, 33, 20, 13), "Tempat Nyimpang Saheulaanan" $(18,24,31,10)$, "Katiga téh Teuing Ku Lila" $(3,6,8,2)$, dan "Séké Béntang" $(19,19,15,10)$; semua sudut pandangnya orang ketiga; gaya bahasa lima cerpen adalah sederhana. 2) Pandangan ekokritik dalam lima cerpen Sunda berkaitan dengan lingkungan, terlihat dari judulnya, juga latar tempat, yang semua ceritanya berada di sebuah pedesaan. Ekokritik yang ada dalam lima cerpen Sunda tersebut membahas mengenai menjaga lingkungan, kerusakan lingkungan, perubahan dan pencemaran lingkungan, serta krisis lingkungan. 3)Karya yang sesuai untuk dijadikan alternatif bahan pelajaran membaca "Carita pondok" di SMA kelas XI, yaitu "Pasir Kiara" karya Yus Rusyana, "Tempat Nyimpang Saheulaanan" karya H. Usép Romli H.M., "Katiga téh Teuing Ku Lila” karya Ruhaliah, dan “Séké Béntang” karya Mamat Sasmita.
\end{abstract}

Kata kunci: carita pondok, struktural, ekokritik, bahan pembelajaran

\section{FIVE SHORT STORIES OF SUNDANESE FOR ALTERNATIVE LEARNING MATERIALS IN READING “CARITA PONDOK” IN SENIOR HIGH SCHOOL AT CLASS XI \\ (Structural and Ecocritical Analysis)}

\begin{abstract}
The background of this study is the lack of human awareness in protecting the environment. As the result is to uncover and describe the structure, ecocriticism of the five Sundanese short stories, and can be used as an alternative material for reading "Carita Pondok" in High School class XI as the nd result. The method of this study is descriptiveanalytic. The result is 1) the structure of the five short stories, ("Pasir Kiara" the theme is about protecting the environment, "Tanah Sakarung" about the political environment and religious, "Tempat Nyimpang Saheulaanan" about economic crises and religious, "Katiga téh Teuing Ku Lila" about environment damage, "Séké Béntang" about protecting the environment); chronological plot ("Pasir Kiara," "Tempat Nyimpang Saheulaanan," "Katiga téh Teuing Ku Lila," and "Séké Béntang") and double groove ("Tanah
\end{abstract}


Sakarung"); the setting of "Pasir Kiara" (21 scene, 28 time, 22 atmosphere, 4 social), "Tanah Sakarung" (10, 33, 20, 13), "Tempat Nyimpang Saheulaanan” (18, 24, 31, 10), "Katiga téh Teuing Ku Lila" (3, 6, 8, 2), and "Séké Béntang" (19, 19, 15, 10); all of it points of view are third person; the five short stories language style is simple. 2) Ecocritical views in the five Sundanese short stories are related to the environment, as seen from the title, also the setting of the place, all of which are in a rural area. The ecocriticism in the five short stories of the Sundanese discusses environmental preservation, environmental damage, environmental pollution and change, and environmental crisis. 3) Works that are suitable to be used as an alternative material for reading lessons "Carita Pondok" in High School class XI, is "Pasir Kiara" by Yus Rusyana, "Tempat Nyimpang Saheulaanan" by H. Usép Romli H.M., "Katiga téh Teuing Ku Lila” by Ruhaliah, and "Séké Béntang” by Mamat Sasmita.

Key words:short story (carita pondok/carpon), structural, ecocriticism, learning materials

\section{PENDAHULUAN}

Dari waktu ke waktu, zaman mengalami perubahan yang semakin pesat, baik alamnya, maupun manusianya. Selaras dengan hal itu, ada banyak dampak yang terjadi, baik itu dampak positif, maupun dampak negatif. Di antara dampak positifnya adalah semakin berkembangnya ilmu pengetahuan, semakin canggihnya teknologi, manusianyapun semakin melek wacana, dan sebagainya. Selain itu, ada pula dampak negatif yang dianggap tidak sesuai dengan norma yang ada di masyarakat. Contohnya, banyak manusia yang tidak peduli terhadap keadaan lingkungannya. Bumi semakin rusak yang disebabkan oleh manusia yang sudah hampir tidak peduli pada lingkungannya, sudah bukan rahasia lagi. Dari bencana alam hingga bencana yang disebabkan oleh ulah manusianya sendiri. Sudah banyak kasus-kasus kebakaran hutan, sungai dan selokan yang tertimbun sampah, yang menyebabkan banjir di mana-mana, lahan-lahan dan kebun (tanah) yang ada di jual (sehingga pribumi terjajah oleh orang asing), termasuk air minum harus dibeli (alam dijadikan sebagai objek komersial), dsb.

Kesadaran manusia akan pentingnya menjaga lingkungan, terasa semakin berkurang. Bukan hanya hubungan manusia dengan lingkungan alamnya, tetapi hubungan pada sesama manusiapun semakin renggang. Seperti yang dijelaskan oleh Endraswara (2016, hlm. 36) bahwa sekarang ini alam hanya dijadikan sebagai objek untuk memenuhi kebutuhan manusia saja.

Hal demikian, dalam karya sastra sudah ada sejak dulu. Para penulis, biasanya mengekspresikan semua yang ada di lingkungan sekitarnya dalam bentuk tulisan, yang disebut karya sastra, dengan cara menjadikan lingkungan sebagai latar (setting), kiasan, atau digunakan sebagai tema, dan judul. Tulisannya tak hanya sekadar luapan emosi atau kondisi lingkungannya semata, tetapi juga salah satu bentuk kritik dari para penulis yang menggambarkan lingkungan mereka, sehingga pembaca dapat mengambil pelajaran dari tulisan tersebut untuk menjalani hidupnya, terutama bagaimana sikap manusia pada alam yang seharusnya.

Penelitian ini diharapkan bisa meningkatkan kesadaran manusia untuk menjaga lingkungan sekitar, demi kelangsungan hidupnya. Sebab, semakin langkanya manusia yang peduli terhadap keadaan sekitarnya (salah satu konsekuensi negatif dari perkembangan zaman). Banyak hal yang terlepas dari 
fitrahnya, seperti yang telah disebutkan sebelumnya. Dengan demikian, peneliti mengambil penelitian tentang ekokritik yang meneliti tentang hubungan sastra dan lingkungan, dan menunjukkan pentingnya menjaga lingkungan, harus dijaga sebagaimana manusia menjaga diri mereka sendiri. Oleh karena itu, jika lingkungan atau alam rusak akan berdampak buruk bagi manusia itu sendiri. Hal tersebut sesuai dengan firman Allah dalam Al-Quran surat ArRum ayat 41 , yang intinya menyatakan bahwa kerusakan alam adalah hasil dari tindakan manusia sendiri dan akan berdampak pada mereka.

Peneliti ingin membahas tentang karya sastra terlebih dahulu, sebelum membahas ekokritik. Karya sastra adalah salah satu hasil ciptaan manusia dalam bentuk tulisan yang tak lepas dari lingkungan di mana karya itu ada. Sastra sebagai salah satu konten media untuk mengekspresikan isi hati atau pikiran (imajinasi) penulis, tentunya penciptaannya akan berdasarkan pada lingkungan sekitar mereka. Menurut Koswara (2013, hlm. 6), di dalam kefiksian dan keartistikannya, esensi sastra adalah adanya nilai-nilai kejujuran dan kebenaran. Yang dimaksud kebenaran dalam karya sastra lebih merujuk pada gambaran kejadian dalam kehidupan sehari-hari, bukan hanya dari ekspresi dari isi hati atau pikiran saja.

Banyak karya sastra (terutama cerpen) yang melibatkan alam, hal itu dapat diamati dari cara pemberian judulnya, menggunakan hal-hal yang berkaitan dengan alam dan lingkungan, misalnya "Pasir Kiara" karya Yus Rusyana, "Janari Simpé di Cijeléreun" karya Aan Merdeka Permana, "Tanah Sakarung," "Tempat Nyimpang Saheulaanan," dan "Sapeuting di Cipawening" karya Usep Romli, "Daun" karya Yus R. Ismail, "Kukupu Hiber dina Beus" karya Chyé Rétty Isnéndés, "Séké Béntang" karya Mamat Sasmita, "Jeruk" karya Lugiena Dé, "Angin
Puyuh" karya Absurditas Malka, dan lain-lain.

Untuk memahami karya sastra, apakah itu termasuk pada karakteristik karya sastra dalam penelitian ini atau tidak, tentunya hal pertama yang dilakukan adalah membaca. Kegiatan membaca yang dimaksud adalah salah satu kegiatan dari empat keterampilan bahasa yang bersifat reseptif. Hal ini sesuai dengan yang dijelaskan oleh Haerudin, Suherman, dan Kardana (2013, hlm. 7) bahwa membaca adalah salah satu keterampilan bahasa yang bersifat resptif aktif. sedangkan menurut Subyantoro (2011, hlm. 9) membaca adalah keterampilan yang semakin lama akan menjadi kebiasaan seseorang. Diharapkan melalui penelitian ini pembaca, khususnya peserta didik dapat membiasakan diri untuk membaca sebagai kegiatan sehari-hari.

Terkait dengan uraian sebelumnya, penelitian ini menggunakan pendekatan ekokritik. pendekatan ini merupakan ilmu yang mempelajari tentang hubungan antara lingkungan dan karya sastra. Menurut Endraswara (2016 hlm. 43) adalah pendekatan ini memiliki dua versi, yaitu versi ekologi sastra dan versi sastra ekologi. sastra ekologi lebih merujuk pada estetika lingkungan dan makna yang ada dalam karya sastra. sedangkan ekologi sastra (ekokritik) lebih mengarah pada hal-hal yang ada di sekitar sastran. Peneliti akan mengambil beberapa judul menjadi sumber data yang akan dianalisis, yaitu "Pasir Kiara" karya Yus Rusyana, "Tanah Sakarung," jeung "Tempat Nyimpang Saheulaanan" karya Usép Romli, "Patok Beureum" karya Tatang Sumarsono, dan "Séké Béntang" karya Mamat Sasmita.

Selain itu, ada pendekatan lain yang digunakan oleh peneliti dilam menggali isi sumber data, yaitu struktural. Pendekatan ini mengkaji tentang bagaimana isi sastra berdasarkan unsur intrinsik atau objektif. Menurut yang dijelaskan oleh Teuw (Koswara, 2013, 
hlm. 20) bahwa strukturalisme adalah pendekatan yang mengkaji karya sastra berdasarkan pada struktur otonomnya. Demikian pula Isrofil (2015 hlm. 52) menyatakan bahwa strukturalisme adalah pendekatan yang mengkaji isi karya berdasarkan strukturnya. Secara garis besar, strukturalisme adalah salah satu pendekatan karya sastra yang berfokus pada analisis objektif (langsung pada unsur intrinsik karyanya). Dari hasil mengkaji unsur struktural, peneliti dapat lebih mudah dalam menganalisis data penelitian menggunakan ekokritik.

Penelitian ini berdasarkan pada banyaknya orang yang membuang sampah sembarangan. Padahal di kota Bandung, misalnya, telah menyediakan tempat sampah di setiap tempat dan ada denda untuk yang membuang sampah sembarangan, tetapi kenyataannya masih ada orang yang melakukan hal ini. Salah satu organisasi non-profit (Greenpeace Filipina) di luar negeri membuat replika paus dari plastik (yang terinspirasi dari peristiwa matinya ikan paus karena memakan sampah plastik), yang bertujuan untuk meningkatkan kesadaran manusia akan pentingnya menjaga lingkungan sebagaimana mestinya. Selain itu, penelitian tentang pendekatan ekokritik dalam bahasa Sunda masih relatif kecil. Dengan demikian, penelitian ini berjudul "Lima Carpon pikeun Alternatif Bahan Pangajaran Maca Carpon di SMA Kelas XI (Kajian Struktural dan Ekokritik)" yang selanjutnya dapat digunakan untuk alternatif bahan pangajaran, yaitu tentang struktur cerita dan isi dari karya sastra (tema lingkungan). Hal ini sesuai dengan Kompetensi Inti (KI) dan kompetensi dasar (KD) dalam Kurikulum 2013 revisi 2017 yang mengharuskan adanya materi cerita pendek di Sekolah Menengah Atas (SMA) kelas XI, KD-na dari "Menganalisis isi, struktur, dan unsurunsur kebahasaan dari 'carita pondok' "(Tim Pengembang Kurikulum Area,
2017, hlm. 25). Penelitian ini juga diharapkan dapat menumbuhkan kesadaran siswa tentang pentingnya menjaga lingkungan melalui pengajaran.

\section{METODE}

Metode yang digunakan dalam penelitian ini adalah deskriptif-analitik. Metode deskriptif-analitik adalah metode digunakan untuk mendeskripsikan hasil penelitian dengan cara menganalisis data sampel atau penelitian (Sugiyono, 2009). Sumber data primer dari penelitian ini adalah lima "Carpon" Sunda yang dipilih dari dua buku, berdasarkan judul, tema, dan isi yang berkaitan dengan lingkungan (Pasir Kiara karya Yus Rusyana, Tanah Sakarung jeung Tempat Nyimpang Saheulaanan karya H. Usép Romli H.M., Katiga téh Teuing Ku Lila karya Ruhaliah, jeung Séké Béntang karya Mamat Sasmita, yang selanjutnya akan disingkat menjadi PK, TS, TNS, KTKL, dan SB). Teknik mengumpulkan datanya menggunakan teknik studi pustaka, dengan instrumen untuk kartu data untuk mempermudah peneliti menganalisis data, karena menurut Setiawan (2017, hlm. 40) bahwa dalam kartu data terdapat informasi tentang kutipan yang mencerminkan struktural dan ekokritik dalam cerpen. Langkahlangkah mengolah datanya adalah membaca lima "Carpon" Sunda yang sudah dipilih sebelumnya, menganalisis struktur dan ekokritik, mendeskripsikan, menafsirkan, dan membuat simpulan, serta membuat laporan.

\section{HASIL DAN PEMBAHASAN}

Berdasarkan hasil analisis ada tiga hal yang perlu diperhatikan, yaitu struktur cerita, kritik lingkungan, dan bahan pelajaran.

\section{Struktur Carpon}

Cerpen $P K$ karya Yus Rusyana mengandung tema menjaga lingkungan, terutama alam. Hal ini bisa dilihat dari sikap tokoh dalam menghadapi 
pembangunan dengan tetap memertahankan tempat peninggalan nenek moyang. Alurnya adalah alur maju, karena ceritanya, meskipun ada bagian yang merepresentasikan keadaan masa lalu. Berdasarkan analisis latar dalam cerita ini ada 21 latar tempat, yang sebagian besarnya merupakan latar tempat di sebuah bukit. Latar waktu ada 28, 22 latar suasana, dan 4 latar sosial. Dari setiap latar, hanya mengambil contoh yang mewakili dari setiap latar. Sedangkan tokoh yang berada dalam cerpen ini terdapat satu tokoh utama, yang bernama Aki Kolot, memiliki watak yang bijaksana, berserah diri, dan memegang teguh keyakinannya. Tokoh pembantu dalam cerita ini adalah sopir, kondektur, ketua panitia, dan para tokoh lainnya yang hanya diceritakan sepintas saja, sehingga wataknya tidak muncul. Judulnya bisa langsung ditemukan dari salah satu latar tempat, yaitu Pasir Kiara. Sudut pandangnya menggunakan sudut pandang orang ketiga dan gaya bahasanya sederhana, sebab bisa langsung dimengerti maksudnya. Hal ini berdasarkan pada teori yang dikemukakan oleh Stanton (2012, hlm. 20) yaitu ketika pembaca sedang membaca salah satu karya sastra ada beberapa hal yang harus diperhatikan, supaya isi atau maknanya tidak menyimpang, yaitu dengan cara menentukan tema, fakta cerita (alur, latar, tokoh), dan sarana carita (judul, sudut pandang, gaya bahasa).

Dalam carpon TS karya $H$. Usép Romli H.M., tema yang diangkat adalah lingkungan politik dan religi. Lingkungan politik bisa dilihat dari pola pikir pada beberapa pelaku yang berlatar sosial pemerintah, sedangkan lingkungan religi bisa dilihat dari pola pikir Ajengan Holil dalam menyelesaikan setiap kasus yang selalu dikaitkan dengan spiritual. Alurnya adalah ganda, karena beberapa bagian menceritakan tentang kejadian di masa lalu. Latar dari hasil analisis ada 10 tempat, 33 waktu, 20 suasana, dan 13 sosial. Tokoh utama dalam cerpen ini adalah Ajengan Holil, Lurah Barja, dan Bapa Bigbos. Ajengan Holil mempunyai watak yang bijaksana, Lurah Barja licik dan mata duitan, dan Bapa Bigbos berwatak mesum. Tokoh pembantunya ada 10, yaitu Indah Jelita, Rosita, Sekdes, Warga, Pa Uja, Hansip Sanadi, Sobana, Komandan Hansip Desa, dan Pa Babina. Setiap watak dari masing-masing tokoh pembantu adalah cantik, manja, tidak jujur, marah, pemaksa, bijaksana, galak, pemarah, dan pengecut. Judulnya berdasarkan dari salah satu kejadian yang menggambarkan salah satu tokoh harus mengangkat tanah satu karung karena dengan licik akan menjual tanah rakyat, tapi ianya tak kuat. Sudut pandangnya adalah sudut pandang orang ketiga dan gaya bahasa yang digunakan adalah bahasa yang sederhana.

Cerita $T N y S$ karya H. Usép Romli H.M. mengambil tema krisis ekonomi dan religi. Karena carpon ini bercerita tentang kesulitan warga kampung Kondang yang lahan tempat mereka bekerja tanah rusak, yang akhirnya dijual. Setelah itu, ada konglomerat yang membeli lahan itu, lalu mendirikan sebuah bangunan yang sempurna. Itu menjadi kebanggaan pemiliknya, tetapi karena di dunia ini tidak ada yang kekal, rumah itupun hanya jadi bangunan kosong yang ditinggalkan oleh pemiliknya. Alur dalam cerita ini termasuk dalam alur maju. Latarnya terdiri dari 18 tempat, 24 waktu, 31 suasana, dan 10 latar sosial. Tokoh utama ada dua, yaitu Aki Samun yang memiliki watak protagonis dan $\mathrm{Pa}$ Janur termasuk antagonis. Dengan tokoh pembantunya ada 18 orang, tetapi tidak memiliki watek itu, hanya sebagai alat menyampaikan informasi sebagai penguat cerita. Judulnya tidak terlihat langsung dalam latar, tapi berupa simpulan dari satu kejadian yang menyebutkan bahwa tidak ada satu halpun yang abadi di dunia. Sudut pandangnya adalah sudut pandang 
orang ketiga dan gaya bahasa yang digunakannya bahasa yang sederhana.

KTKL karya Ruhaliah adalah cerita yang mengambil tema tentang kerusakan lingkungan, sebab mengangkat permasalahan tentang musim kemarau yang lebih lama daripada sebelumnya, hal itu adalah akibat dari penjualan mata air. Alur pada cerita ini termasuk dalam alur maju. Latarnya dibagi menjadi 3 tempat, 6 waktu, 8 suasana, dan 2 sosial. Tokoh utama bernama Si Abah, yang memiliki watak pintar dan kritis. Tokoh pembantu dalam cerita ini adalah Pamajikan Si Abah (berwatak kritis), Ki Adi (berwatak pekerja keras), dan Ceu Tari juga adik ipar $\mathrm{Ki}$ Adi tidak mempunyai watak, sebab hanya diceritakan sekilas. Judulnya langsung terlihat dari salah satu peristiwa yang diangkat pada cerita, yaitu tentang lamanya musim kemarau dibandingkan musim sebelumnya. Sudut pandangnya adalah sudut pandang orang ketiga dan menggunakan gaya bahasa yang sederhana.

Cerita $S B$ karya Mamat Sasmita memiliki tema yang sama dengan cerpen $P K$ karya Yus Rusyana, yaitu untuk menjaga lingkungan. Hal ini terlihat dari interaksi tokoh Kang Sabri yang mempertahankan kebun warisan keluarga untuk kepentingan masyarakat. Memiliki alur maju. Latar cerita ini terdiri dari 19 tempat, 19 waktu, 15 suasana, dan 10 sosial. Dalam cerita ini ada tokoh utama dan pembantu. Tokoh utama bernama Kang Sabri, ia memiliki watak pemikiran matang, nyantri, dan konsisten. Sedngkan tokoh ada 9 orang, sementara yang wataknya bisa diamati hanya 3 orang, yaitu Ajengan Falah, Haji Sobirin, dan Yuyum. Masing-masing wataknya adalah bijaksana, perasa, dan pemalu. Selain itu, ada tokoh-tokoh lain yang hanya diceritakan sepintas. Judulnya diambil dari salah satu latar tempat yang menjadi inti permasalahan dalam cerita, yaitu mata air yang bernama Séké Béntang. Sudut pandangnya adalah sudut pandang orang ketiga dan gaya bahasa yang digunakan merupakan bahasa yang sederhana.

\section{Kritik Lingkungan}

Setelah dianalisis strukturalnya, lima carpon Sunda dianalisis kembali menggunakan pendekatan ekokritik. Hal yang dianalisis adalah mengenai hubungan lingkungan dengan struktur cerita, serta kritik lingkungan yang disampaikan dalam karya tersebut. Hubungan lingkungan dan struktur yang terdapat pada lima carpon yang diteliti tidak akan terlepas dari lingkungan. Hal tersebut bisa dilihat dari cara memberi latar, khususnya latar tempat, latar tempat yang ada adalah pedesaan.

Hubungannya dengan struktur cerita $P K$ karya Yus Rusyana, pertama tditemukan dalam pemberian judul terhadap karya tersebut, yaitu Pasir Kiara. Pasir adalah salah satu tempat yang serupa dengan gunung yang tidak mengerucut, tapi memanjang (Danadibrata, 2015, hlm. 507). Sedangkan kiara merupakan salah satu nama kayu. Dari judul tersebut, ada unsur toponiminya, yaitu asal muasal satu "pasir" yang dibeut Pasir Kiara, dikarenakan di pasir tersebut ada sebuah pohon kiara yang sudah berumur ratusan tahun dan tidak roboh termakan waktu, seperti kutipan ini:

“... Tangkal kiara anu meureun geus ratus taun umurna, angger kénéh ngarunggunuk, henteu pugur ku usum. Kapan éta téh pananggeuhan urang lembur. ... Éta pasir anu katelahna Pasir Kiara, lir jadi paseuk mungguh keur urang dinya. ..."

Selain itu, terlihat juga dari latar tempat. Cerita ini mengambil latar tempat di sebuah pedesaan yang mengalami pembangunan. Hal tersebut ditandai dengan adanya lahan-lahan pabrik dan komplek perumahan. Terlihat dari adanya pesawahan, pabrik, komplek perumahan, pasir (bukit), dan balai desa. Dan latar waktu, berlatar pada masa pemerintahan 
orde baru. Waktu itu sedang digembargemborkan pembangunan di setiap daerah. Dari situ bisa dilihat bahwa sedang adanya perubahan, termasuk lingkungan alam. Begitu pula Pasir Kiara, yang pada saat itu menjadi objek pembangunan.

Carpon PK karya Yus Rusyana, mengandung kritik lingkungan tentang menjaga lingkungan, kerusakan lingkungan, serta perubahan zaman dan pencemaran lingkungan.

\section{Menjaga Lingkungan}

Isinya berupa kritik pengarang terhadap keadaan lingkungan di masa pemerintahan orde baru. Pada masa itu, sedang digembar-gemborkan pembangunan negara, tapi di sisi lain ada beberapa pihak yang mengutamakan pembangunan tanpa mempedulikan nilai kebudayaan (nilai rohaniah) di suatu tempat yang akan dirubah demi kepentingan pembangunan, yang sesungguhnya hal tersebut sangat penting bagi jati diri kita.

Melalui peran Aki Kolot, pengarang ingin menyampaikan kritik atau pendapatnya terhadap keadaan waktu itu. Pengarang ingin mempertahankan nilai kebudayaan Pasir Kiara, yang menjadi ciri warga desa sekitarnya. Hanya saja, karena Aki Kolot suudah etrlalu tua, ia sudah tak berdaya untuk melawannya. Dia hanya bisa berserah diri kepada Tuhan, meminta petunjuk tentang apa yang seharusnya ia lakukan untuk melindungi apa yang ia lindungi dengan sepenuh hati. Tapi, ia juga tak memungkiri hasil dari mendongkrak batu di Pasir Kiara itu bisa menjadi mangpaat untuk semuanya.

\section{Kerusakan Lingkungan}

Selain menjaga lingkungan, cerita ini juga menceritakan tentang kerusakan lingkungan, khususnya di Pasir Kiara. Hal tersebut disebabkan oleh perilaku manusia, yang katanya demi mencukupi kebutuhannya. Bagian tersebut dibahas pada halaman 166, kutipannya:

"Puguh, éta pasir anu ngajegir téh ayeuna mah geus aya nu ngagunasika. Kapan pongpokna belah wétan geus ditalugaran, diarah batuna. Unggal poé, ti isuk jedur tepi ka soré jedér, pulang anting treuk aya puluhna, ngunjalan batu keur ngawangun perumahan, pabrik, jambatan (sasak), jeung wawangunan séjénna. Jadi, éta pasir anu tohaga téh geus ilang kadigjayaanana. ..."

\section{Parubahan Zaman dan Pencemaran Lingkungan}

Di awal cerita, pengarang menceritakan tentang perubahan alam dari masa dulu sampai sekarang, masa pembangunan. Pada bagian itu, pengarang merasa prihatin terhadap pencemaran lingkungan yang disebabkan oleh kemajuan zaman. Hal tersebut bisa dilihat dari kutipan:

“... Piraku teu kabireungeuh, kapan kotakan-kotakan anu di sisi jalan mah geus nungtut diadegan wawangunan,. Aya lelewek-lelewek anu geus gegek ku imah. Atuh sok sanajan tacan diadegan, loba kotakan anu geus dituhurkeun, tur ditingker ku pager kawat atawa ku kuta beton. Geura ituh sidikkeun, sapanjang jalan anu ngendat aya anu ngabarakbak. Éta téh wawangunan pabrik. Rupa-rupa pabrik anu rarohaka diadegkeun di tengahtengah alam anu sakitu halonna. Tuh geuning haseupna tina corobong mumbul jadi reueuk di langit. Nandakeun yén urang eukeur pahibut kuriak badag. Wahangan anu ti kajauhan mah katémbong bangun canémbrang hérang, caina ngabeuleugeudeur héjo pinuh ku olab pabrik."

Analisis di atas berdasarkan pada teori yang disampaikan oleh Garrard (dalam Sukmawan, tanpa taun, hlm. 3) bahwa ekokritik bisa menuyun dalam 
menentukan, mengeksplorasi, serta memecahkan masalah ekologi dalam artian yang lebih luas. Dalam fungsinya sebagai media representasi sikap, pandangan, dan pendapat masyarakat terhadap lingkungan sekitarnya, sastra mempunyai potensi untuk menyampaikan gagasan tentang lingkungan, termasuk nilai-nilai kearifan lingkungan. Begitu pula menurut Endraswara (2016, hlm. 72) ekologi merupakan kondisi yang ada di sekitar pengarang. Kepekaan pengarang pada kondisi sekelilingnya bisa berupa memahami suasana ekologis, di antarana: (1) situasi lingkungan yang rusak, banyak yang demo, banyak sampah, dan tata ruang yang semakin berantakan; dan (2) keadaan alam yang nyaman, tentram, aman, damai, dan memberi inspirasi untuk hidup.

Dalam cerpen $T S$ karya $H$. Usép Romli H.M., dalam judulnyapun akan langsung terlihat bahwa hal ini ada kaitannya dengan lingkungan, yaiu alam. Adapun dalam tema yang diangkatnya adalah mengenai lingkungan, tapi selain lingkungan alam, juga ada lingkungan politik, khususnya di desa Kelewih. Lingkungan alamnya mengangkat masalah tentang jual-beli tanah. Sedangkan lingkungan pulitiknya, lebih membahas lingkungan yang berkaitan dengan Korupsi, Kolusi, dan Nepotisme (KKN) serta kehidupan pejabatnya yang suka mempermainkan wanita.

Bisa dilihat dari cara pengarang memilih latar tempat yang menceritakan tentang pedesaan. Hal tersebut ditandai dengan adanya kutipan di awal cerita:

"Saha nu teu kataji ku tanah rata?

Ngampar di mumunggang pasir?

Bahé ngalér? Nyambung kana situ hiang nu masih kénéh caian canémbrang hérang?"

Selain itu, adanya interaksi tokoh dan lingkungannya. Dalam cerita ini, Ajengan Holil dan warga menolak adanya korupsi, kolusi, dan nepotisme di lingkungan aparat desa.
Cerita ini lebih kepada kritik pengarang terhadap keadaan politik, yang terlibat pada kasus KKN (Kolusi Korupsi dan Nepotisme). Kritik tersebur disampaikan dengan cara memunculkan tokoh Bapa Bigbos dan Lurah Barja. Perilaku Bapa Bigbos, yang diceritakan sebagai pensiunan pejabat (pulisi ataupun tentara) yang mata keranjang, sehingga ia kawin siri dengan Indah Jelita, artis baru yang cantik. Begitupun Lurah Barja, ia digambarkan mata keranjang dan suka memanfaatkan keadaan demi keuntungannya pribadi, yaitu dalam cerpen ini diceritakan bahwa ia mengambil untung yang sangat besar dari lahan warga yang baru akan dijual, dengan harga yang biasanya dua ratus ribu satu tumbak dinaikkam jadi tujuh ratus ribu. Hal tersebut dilakukan untuk membelikan Honda Jazz pada Rosita dan sebagai iming-iming untuk mendekati Néng Yénni, pegawai bank kecamatan. Dari dua situasi tersebut pengarang menggambarkan keadaan yang terjadi di lingkungan politik waktu itu.

Selain itu, pengarang menyampaikan suatu hal tentang bagaimana sikap manusia dalam menghadapi keadaan lingkungan yang seharusnya, yaitu menjaga lingkungan.

\section{Menjaga Lingkungan}

Dalam cerita ini, pengarang menginginkan manusia bisa melawan dengan cara mempertahankan lingkungan. Melalui aksi demo yang dilakukan oleh warga kampung Kondang yang tanahnya ditawar dengan harga yang sangat rendah, tapi warga merasa dirugikan dengan hal tersebut. Jadi, warga ingin mempertahankan tanahnya. Hal tersebut dapat dilihat dari kutipan:

"'Ieu, pangersa, perkawis tanah Pasir Pangematan,' Pa Uja, anggota BPD nerangkan. 'Kumaha kitu?' cék Ajengan Holil. Derekdek Pa Uja nerangkeun. Cenah, aya laporan, urang Pasir Pangematan ngarasa dipaksa pirusa ku Hansip Sanadi 
sangkan ngajual tanah lima puluh rébu satumbak. Lain saurang dua urang nu ngarasa dipaksa téh. Aya kana welasna."

Dilihat dari judulnya, cerpen $T N y S$ karya H. Usép Romli H.M. tidak menggambarkan hubungannya dengan lingkungan, tapi jika dilihat dari tema dan isi yang dianalisis, temanya sebagian tentang krisis lingkungan. walaupun hal tersebut hanya ada pada awal cerita. Pengarang memberi gambaran bagaimana interaksi tokoh menghadapi masalah di lingkunganya. Dalam cerita ini, masalahnya tentang lahan pesawahan yang tadinya terkena longsor, lalu tanahnya semakin lama semakin rusak karena terlalu sering memakai pupuk dan obat-obatan kimi untuk membasmi hama. Di situ, ada pola pikir tokoh yang menandakan sudah merasa jengah terhadap keadaan tersebut. Akibatnya, tokoh menjual tanahnya.

Selain itu, di awal cerita ada latarlatar suasana dan tempat yang menggambarkan hubungannya terhadap lingkungan. Latar tersebut bisa dilihat dari adanya rasa takut para petani di desa Kondang, akibat lahan tempat mereka bekerja semakin rusak, sehingga mengakibatkan adanya kelaparan atau paceklik. Hal tersebut dapat dilihat dari kutipan:

"Kawas nu sarua deuih pipikiranana. Kumalayang kana tanah. Kana kasab tatanén. Beuki dieu, tanah beuki balangsak. Lantaran digeder ku gemuk pabrik. Rasa mokaha nu ngamimitian, keur karék jol bangsa uréa jeung NPK. Leuwih matih ti batan gemuk kolong, gemuk kandang, atawa kompos. Sakali ngawurkeun uréa sakilo, paré sakotak gancang lilir. Gancang ngémploh. Beuki diweleg, beuki génjah."

Latar tempat yang mengambil latar pedesaan. Hal tersebut dapat dilihat pada kutipan:
"Ninggang di lembur Kondang. Nyelegon handapeun léngkob pasir nu patingjungkiring di madhab papat. Ukur aya lolongkrang béh wétan. Sesela antara Pasir Honjé jeung Pasir Hanjuang. Lebah dinya aya curug. Nutug. Ngocorkeun cai ka walungan Cipamarakan. Ti lebah dinya deuih, cahaya panonpoé nyélékét. Ngahibaran lembur anu unggal isuk diharudum halimun."

Ada juga yang menyebutkan masa orde baru, ditandai dengan membahas tentang bibit unggul. Dalam sejarah, bibit unggul berawal pada masa pemerintahan orde Soeharto, yaitu adanya Repelita (Rencana Pembangunan Lima Tahun) serta krisis pangan. Hal tersebut dapat dilihat dari kutipan:

"Nu ngariung aranteng. Nyapék oyék. Ngararasakeun pelemna éta kadaharan tina sampeu meunang ngeueum, nyeupan, jeung moé. Nepi ka jiga béas. ... '...Aya paréntah ti désa, binih paré kudu ganti. Usum melak kudu bareng waktuna. Inget wé, sawah Mama Haji Kodir, geus ditanduran, dicabutan deui. Mangkaning binih ségon alus. $\mathrm{Nu}$ pulen. Ceuk nu maréntah paré samodél kitu mah lila. Genep bulan karék kaala. Bibit anyar mah ti barang ceb ukur saratus poé' 'Enya nu disebut bibit unggul téa,' Kang Edon némpas,"

Pengarang menyampaikan kritiknya dengan cara menggambarkan keadaan lingkungan di desa Kondang. Terutama pesawahan yang menjadi tempat utama warga untuk bekerja. Kritiknya yaitu kerusakan lingkungan.

\section{Kerusakan Lingkungan}

Sawah-sawah yang ada, tanahnya semakin rusak, akibat dari terlalu sering memakai pupuk pabrik. Hal tersebut mengakibatkan munculnya hama wereng yang sulit untuk dibasmi dengan cara yang biasa saja, sehingga harus memaksakan diri membeli obat. Selain 
itu, setiap hewan yang ada di situpun ikut mengalami kepunahan. Diceritakan pula adanya pergantian bibit secara paksa, yang mengakibatkan adanya kelaparan/kesenjangan pangan ketika masa orde baru. Hal tersebut akibat dari kedatangan bibit unggul ysng begitu lamban. Sebab, tanah atau lahan pekerjaan warga Kondang semakin rusak. Akibatnya para warga terpaksa menjualnya. Hal tersebut dapat dilihat dari kutipan:

"Kawas nu sarua deuih pipikiranana. Kumalayang kana tanah. Kana kasab tatanén. Beuki dieu, tanah beuki balangsak. Lantaran digeder $\mathrm{ku}$ gemuk pabrik. Rasa mokaha nu ngamimitian, keur karék jol bangsa uréa jeung NPK. Leuwih matih ti batan gemuk kolong, gemuk kandang, atawa kompos. Sakali ngawurkeun uréa sakilo, paré sakotak gancang lilir. Gancang ngémploh. Beuki diweleg, beuki génjah. Tungtungna kajongjonan. Ngeungeunaheun. Butuh gemuk kari indit ka toko. Teu kudu dekal-dekul ngeduk jeung nanggung. Bau tur kotor. Ngan édas hamana. Jul-jol bangsaning bangbung leutik nu disebut wereng.aya nu hideung, aya nu coklat. Sakali eunteup ngabubuhan, pelak paré maju ka reuneuh, géhéng lir tapak ngaduruk. Atuh kapaksa keur ngabasmina kudu meulian deui obat anti hama buatan pabrik '...Aya paréntah ti désa, binih paré kudu ganti. Usum melak kudu bareng waktuna. Inget wé, sawah Mama Haji Kodir, geus ditanduran, dicabutan deui. Mangkaning binih ségon alus. $\mathrm{Nu}$ pulen. Ceuk nu maréntah paré samodél kitu mah lila. Genep bulan karék kaala. Bibit anyar mah ti barang ceb ukur saratus poé' 'Enya nu disebut bibit unggul téa,' Kang Edon némpas, 'Ngan hanjakal teu bisa ngabinihkeun sorangan. Kudu meuli deui binih anyar. Teu kawas ségon Mama Haji Kodir..."
Dilihat dari judulnya, cerita $K T K L$ karya Ruhaliah berkaitan dengan lingkungan, yaitu keadaan lingkungan ketika kemarau panjang. Katiga merupakan kata lain halodo dalam bahasa Sunda. Sedangkan latar tempat yang diceritakan termasuk pada daerah pedesaan, hal tersebut dapat dilihat dari kutipan:

"Nya ari sumurna nu deukeut pasar, atawa deukeut pabrik mah pantes wé, perlu ogé, lantaran caina pasti kotor. Ari modél urang, cicing di lembur, euweuh pabrik euweuh naon, cai hérang jeung beresih, na maké kudu kabawakeun."

Dalam cerita ini unsur ekokritik yang diangkatnya adalah krisis lingkungan.

\section{Krisis Lingkungan}

Krisis lingkungan di sini karena warga-warga yang mempunyai mata air menjualnya, karena tergiur oleh uang. Akibatnya, kemarau yang dirasa oleh Si Abah dan semua warga kampung berkepanjangan. Sampai-sampai para petani tidak bisa memanfaatkan lahan pesawahannya, untuk mencukupi kebutuhannya sehari-hari. Selain warga sekitar, ternyata warga kotapun merasakan akibatnya. Hal tersebut bisa dilihat dari kutipan:

"Mémang saréréa. Nu cicing di kota ogé geus ribut teu boga cai. Cai lédeng ogé geus aya bulanna teu ngocor. Atuda cai lédeng ogé lolobana mah ti wahangan. Ari ayeuna wahanganana saat. Nya akibatna lédeng ogé garing. $\mathrm{Nu}$ boga duit gedé onaman bisa meuli cai diténgkian, ari nu teu boga mah dikompanan atawa ditanggungan. Mangkaning satanggungan téh sarébu. Mending mun mahi lima tanggungan.' ... 'Nu leuwih ripuh mah nu tani jiga urang. Apan mindeng kabéjakeun paraséa alatan parebut cai."'"

Jika dilihat dari judul, cerpen $S B$ termasuk ke dalam ekokritik, sebab kata 
séké dan béntang merupakan bagian dari alam. Begitupun temanya yang mengangkat tentang menjaga lingkungan. Sebagian besar latarnya adalah latar suasana yang menceritakan keindahan suatu kebun serta manfaat mata air di dalmnya untuk kepentingan umum. Di sini, interaksi antara pola pikir tokoh dan lingkungannya terlihat dengan jelas. Sebab, tokoh utama berpikiran bahwa ia harus bisa menjaga dan mempertahankan lingkungan demi kepentingan umum, dari pribadinya.

Dalam cerpen ini, pengarang menyampaikan kritiknya tentang lingkungan, khususnya lingkungan alam, yaitu menjaga lingkungan.

\section{Menjaga Lingkungan}

Terlihat dari watak tokoh utama yang ingin menjaga kebun warisan keluarganya, supaya bisa bermanfaat bagi semua. Daripada dijual ke orang asing, yang nantinya akan mengakibatkan adanya masalah lain. Maksud dari masalah ini adalah dengan dijualnya kebun tersebut tentu akan berpengaruh pada kepentingan umum, yang sebagian hidupnya bergantung pada mata air di kebun tersebut. Jika hal tersebut terjadi, warga takut tidak bisa memanfaatkan tempat itu untuk mencukupi kebutuhan hidupnya. Hal tersebut dapat dilihat dari kutipan yang menunjukkan bahwa Kang Sabri (tokoh utama) tidak menjual Séké Béntang:

"Aya nu nanya ka juru tulis désa perkara Séké Béntang dina waktu kariaan kawin Kang Sabri, dijawabna tandes pisan, 'Teu cios diical, da nu badé mésérna mundur margi abot saratna.' 'Naha naon saratna téh?' 'Kedah nawis perjanjian di payuneun notaris, nu eusina moal ngakut cai sanaos mung sagelas plastik.",

Cara tokoh Kang Sabri dalam menjaga lingkungannya terbilang unik, sebab ia mengambil kesempatan dari berita dijualnya Séké Béntang untuk membantu biaya pernikahannya.

\section{Bahan Pelajaran}

Setelah tahap tersebut dilakukan, lalu lima carpon Sunda diteliti kembali, mana yang lebih cocok untuk dijadikan alternatif bahan pembelajaran, dianalisis berdasarkan pda isi dari setiap karya. Dari situ, peneliti menemukan empat karya yang sudah memenuhi semua kriteria memilih bahan pembelajaran yang disampaikan oleh Haerudin dan Kardana, yaitu Pasir Kiara, Tempat Nyimpang Saheulaanan, Patok Beureum, jeung Séké Béntang.

Dalam menentukan, guru harus memenuhi beberapa kriteria bahan ajar, supaya bahan yang dipilih sesuai dengan tujuan pembelajaran. Dan menurut Haerudin dan Kardana (2013, hlm. 77) ada beberapa kriteria bahan ajar berdasarkan lima hal, yaitu:

a. Tujuan yang ingin dicapai, yaitu peserta didik bisa mengetahui bagaimana akibat dari tidak menjaga lingkungan dan mencontoh sikap dalam menjaga lingkungan.

b. Dianggap mempunyai nilai untuk kehidupan manusia, yaitu jika lingkungan (alam) dijaga tentu lingkungan akan menjaga pula, sebab lingkungan adalah salah satu sumber untuk mencukupi kebutuhan seharihari.

c. Dianggap mempunyai nilai sebagai warisan dari generasi sebelumnya, yaitu peserta didik bisa belajar bagaimana orang tua zaman dulu menjaga lingkungannya.

d. Ada gunanya untuk menguasai suatu keilmuan, yaitu peserta didik bisa belajar dari peristiwa yang ada dalam cerita.

e. Sesuai dengan minat dan kebutuhan peserta didik, yaitu peserta didik memerlukan pengetahuan dalam menumbuhkan sikap menjaga lingkungan.

Sedangkan cerpen TS karya H. Usép Romli H.M. tidak memenuhi kriteria. Sebab dalam isi ceritanya ada bagian 
yang dianggap bisa merusak moral peserta didik. Bagian tersebut mengandung unsur-unsur erotis.

\section{SIMPULAN}

Berdasarkan hasil analisis dan pembahasan, bisa disimpulkan seperti di bawah ini.

a. Struktur cerita pada lima carpon Sunda yaitu: 1) ada tiga carpon yang mengangkat tema tentang lingkungan alam dan dua lainnya tentang lingkungan pulitik-religi jeung krisis ekonomi-religi; 2) empat carpon alurnya maju dan carpon TS karya $\mathrm{H}$, Usép Romli H.M. ganda; 3) semua latarnya berada di pedesaan; 4) tokoh utamanya ada yang seorang, dua orang, tiga orang, dan tokoh pembantunya ada yang hanya diceritakan sekilas; 5) judulnya ada yang diangkat dari salah satu kejadian dan ada juga yang dari latar; 6) sudut pandang yang digunakan adalah sudut pandang orang ketiga; dan 7) gaya bahasa yang digunakannya adalah bahasa yang sederhana.

b. Ekokritik yang ada dalam lima carpon Sunda digolongkan ke dalam dua bagian, yaitu hubungan antara lingkungan dan struktur cerita serta kritik lingkungan. Berdasarkan hasil analisis, semua cerpen yang ada dalam penelitian ini mempunyai hubungan dengan lingkungan. Dari segi judul sudah terlihat bahwa hal tersebut menunjukkan adanya keterkaitan dengan lingkungan. Begitu pula jika dilihat dari latar tempat, yaitu tempat yang berkaitan dengan pedesaan yang menjadi salah satu ciri hubungan lingkungan dengan struktur pada cerita. Sedangkan kritiknya menunjukkan adanya unsur menjaga lingkungan, parubahan dan pencemaran lingkungan, kerusakan lingkungan, dan krisis lingkungan. c. Berdasarkan hasil analisis dari bab ssebelumnya, ada empat dari lima carpon Sunda yang sesuai untuk dijadikan alternatif bahan pembelajaran membaca "carpon". Sebab, karya tersebut dianggap sudah memenuhi kriteria dalam memilih bahan ajar, yang dilihat dari isi bacaannya. Sedangkan yang satu lagi tidak sesuai, karena isinya mengandung unsur erotis.

\section{Pustaka Rujukan}

Danadibrata, R.A. 2015. Kamus Basa Sunda. Bandung: Kiblat.

Endraswara, Suwardi. 2016. Metodologi Penelitian Ekologi Sastra: Konsep, Langkah, dan Penerapan. Yogyakarta: CAPS.

Haerudin, D. jeung Kardana, K. 2013. Panganteur Talaah Buku Ajar. Bandung: JPBD FPBS UPI.

Haerudin, D., Suherman, A., \& Kardana, K. 2013. Panganteur Kaparigelan Ngaregepkeun. Bandung: JPBD FPBS UPI.

Isrofil, Nur. 2015. Analisis Struktural Novel Rangsang Tuban Karya Padmasusastra dan Pembelajarannya di SMA. Jurnal Program Studi Bahasa dan Sastra Jawa_UniversitasMuhammadiyah Purworejo. 06 (05): 52. [Online] diakses tangga 14 Oktober 2017 di http://ejournal.umpwr.ac.id/index. php/aditya/article/view/2260

Koswara, Dedi. 2013. Racikan Sastra: Pangdeudeul Bahan Perkuliahan Sastra Sunda. Bandung: Jurusan Pendidikan Bahasa Daerah.

Setiawan, Herman. 2017. Kumpulan Carpon Sapeuting di Cipawening Karya Usép Romli H. M. pikeun Alternatif Bahan Pangajaran Maca Carpon di Kelas X SMA (Ulikan Struktural jeung Ekokritik). Fakultas Pendidikan Bahasa dan Sastra, Universitas Pendidikan Indonesia, Bandung. Tidak diterbitkan. 
Stanton, Robert. (2012). Teori Fiksi Robert Stanton. Yogyakarta: Pustaka Pelajar.

Subyantoro. 2011. Pengembangan Keterampilan Membaca Cepat. Yogyakarta: Graha Ilmu.

Sugiyono. 2009. Metode Penelitian Kuantitatif, Kualitatif dan $R \& D$. Bandung: Alfabeta.

Sukmawan, Sony. (Tanpa taun). Modelmodel Kajian Ekokritik Sastra. [Online] diakses tanggal $22 \mathrm{Mei}$ 2017 di http://fib.ub.ac.id/wrpcon/uploads/1-MODEL-KAJIANKEARIFAN-LINGKUNGANDALAM-SASTRA.pdf

Tanpa nama. 2013. Al-Qur'an dan Terjemahannya (Mushaf Aminah). Jakarta: Alfatih.

Tim Pengembang Kurikulum Tingkat Daerah, 2017. KURIKULUM
TINGKAT DAERAH MUATAN LOKAL (Mata Pelajaran Bahasa dan Sastra Sunda Berbasis Kurikulum 2013 Revisi 2017 Jenjang SMA/SMK/MA/MK). Bandung: Dinas Pendidikan Provinsi Jawa Barat.

\section{UCAPAN TERIMA KASIH}

Puji dan syukur, peneliti panjatkan kepada Dzat Yang Maha Kuasa, yang telah menciptakan dan melancarkan peneliti dalam menyelesaikan jurnal ini. Terima kasih kepada dosen pembimbing Bapak O. Solehudin dan Bapak Agus Suherman, serta kepada seluruh Dosen Departemen Pendidikan Bahasa Sunda yang telah membimbing dan mendukung peneliti dalam menyelesaikan artikel ini. 